\title{
PEMANFAATAN LIMBAH LUMPUR AKTIF PADAT DAN ABU CANGKANG SAWIT INDUSTRI CRUMB RUBBER UNTUK PUPUK ORGANIK DENGAN PENAMBAHAN MIKROBA
}

\author{
UTILIZATION OF SOLID ACTIVE WASTE AND ABOUT CANGKANG SAWIT \\ CRUMB RUBBER INDUSTRY FOR ORGANIC FERTILIZER \\ WITH ADDITIONAL MICROBA
}

\author{
Chasri Nurhayati \\ Balai Riset dan Standardisasi Industri Palembang \\ JI Perindustrian II No 12, Sukarami, Palembang, 30152 \\ email: chasrinurhayati@yahoo.com
}

Diterima : 04 Mei 2019; Direvisi : 04 Mei - 25 Juli 2019; Disetujui : 25 Juli 2019

\begin{abstract}
Abstrak
Limbah lumpur aktif padat industri crumb rubber belum dimanfaatkan secara optimal. Untuk mendukung penerapan Industri Hijau, perusahaan tersebut harus memanfaatkan kembali limbah untuk produk yang bernilai seperti pupuk organik dengan penambahan mikroba. Kegiatan penelitian dimulai dari persediaan bahan baku, pembuatan pupuk organik, penambahan mikroba. Percobaan menggunakan Rancangan Acak Lengkap Faktorial dengan variasi perbandingan bahan baku pupuk organik yaitu limbah lumpur aktif padat: limbah abu dan limbah sekam padi, dengan perbandingan $\left(A_{1}\right)$ 100:0:0 $\left(A_{2}\right)$ 90:5:5 $\left(A_{3}\right)$ 80:10:10 $\left(A_{4}\right)$ 70:15:15 $\left(A_{5}\right)$ 60:20:20, dan konsentrasi penambahan mikroba (EM-4) $B_{1}(1 \%)$, dan $B_{2}(2 \%)$. Pupuk dilakukan dekomposisi selama 40 hari, dan pengujian pupuk organik meliputi visual pupuk, unsur makro. Hasil penelitian terbaik adalah perlakuan $\mathrm{A}_{5} \mathrm{~B}_{2}$ dengan nilai unsur hara makro, bahan organik $24,90 \%$, nitrogen total $0,82 \%$, $\mathrm{P}_{2} \mathrm{O}_{5}, 0,42 \%, \mathrm{~K}_{2} \mathrm{O} 0,39 \%$ memenuhi persyaratan mutu pupuk organik dari sampah organik domestik nomor SNI 19-7030-2004 dan Permentan No. 79/permentan/SR/140/10/2011.
\end{abstract}

Kata kunci : abu, EM-4, limbah lumpur aktif, pupuk organik

\section{Abstract}

Solid active waste Industrial crumb rubber waste has not been utilized optimally.implementation of the green Industry, the company must reuse waste for valuable products such as organic fertilizer with the addition of microbes. Research activities started from the supply of raw materials, making organic fertilizers, adding microbes. The experimental model uses a Factorial Completely Randomized Design with variations in the comparison of raw materials of organic fertilizer, solid activated sludge waste: ash waste and rice husk waste, with a ratio of $\left(A_{1}\right)$ 100: 0: $0\left(A_{2}\right)$ 90: $5: 5\left(A_{3}\right)$ 80: 10:10 $\left(A_{4}\right)$ 70:15:15 $\left(A_{5}\right)$ 60:20:20, and the concentration of microbial additions (EM-4) $B_{1}(1 \%)$, and $B_{2}(2 \%)$. Fertilizers are decomposed for 40 days, testing of organic fertilizer includes visual fertilizers, macro elements,. The best results have treatment $A_{5} B_{2}$ with macro nutrient values, organic ingredients $24.90 \%$, total nitrogen (0.82\%), $\mathrm{P}_{2} \mathrm{O}_{5}(0.42 \%), \mathrm{K}_{2} \mathrm{O}(0.39 \%)$ according the quality requirements of organic fertilizers from organic waste domestic, SNI 19-7030-2004 and Permentan No. 79/permentan/SR/140/10/2011.

Keywords : ash, EM-4, activated sludge waste, organic fertilizer

\section{PENDAHULUAN}

Pabrik Karet Remah (Crumb Rubber) pada umumnya mengolah limbah cairnya menggunakan sistem lumpur aktif karena sistim ini merupakan sistim pengolahan limbah paling optimal dalam menurunkan kandungan BOD dan COD limbah karet remah sampai memenuhi baku mutu. Jumlah limbah yang dihasilkan oleh pabrik crumb rubber dengan kapasitas produksi 5000 ton per hari akan menghasilkan limbah sebanyak
$500 \mathrm{~m}^{3}$. Penanganan terhadap limbah padat lumpur selama ini hanya dibuang ke tempat pembuangan untuk bahan timbunan jalan, atau disebarkan ke tanaman di sekitar pabrik. Menurut Ferguson (1991), pembuangan limbah secara open dumping, baik di dalam atau di luar pabrik berpotensi terhadap terjadinya pencemaran air permukaan dan air tanah. Penanganan limbah ini selain memerlukan biaya operasional, juga belum optimum. Limbah lumpur aktif mengandung mikroorganisme, 
diantaranya jamur, bakteri dan juga protozoa. Hasil pengujian limbah lumpur aktif mengandung unsur hara makro pupuk organik seperti C- organik 31$32,16 \%, \quad \mathrm{C} / \mathrm{N} 27,98-28,97 \%$, nitrogen $1.11-1,32 \%, \quad \mathrm{P}_{2} \mathrm{O}_{5} \quad 1,21-1,31 \%, \quad \mathrm{~K}_{2} \mathrm{O}$ 0,11-0,13\% (Nurhayati, 2016). Kandungan unsur tersebut menjadikan limbah tersebut dapat digunakan sebagai bahan baku pupuk organik (Ferguson, 1991).

Selain itu limbah abu yang merupakan sisa pembakaran boiler pada pabrik crumb rubber menjadi permasalahan. Limbah ini dihasilkan dari pemanfaatan energi biomasa cangkang kelapa sawit, yang berguna untuk proses pengeringan blanket kering menjadi karet remah. Limbah abu yang ditinggalkan dari pemanasan boiler cukup tinggi. Menurut Suwardin (2015), konsumsi bahan bakar biomassa cangkang sawit di daerah Kalimantan Barat sebesar 123,8 $\mathrm{Kg}$ per ton crumb rubber. Proses pengeringan crumb rubber menggunakan boiler dengan bahan bakar cangkang sawit lebih murah dibandingkan bahan bakar solar. Biaya bahan bakar cangkang sawit untuk pengeringan crumb rubber berkisar Rp 77,4-Rp 78 per $\mathrm{Kg}$, sedangkan biaya pegeringan menggunakan bahan bakar solar mencapai Rp 275 per $\mathrm{Kg}$. Penggunaan cangkang sawit sebagai pemanas boiler pada pengeringan crumb rubber merupakan upaya yang tepat dalam mengganti bahan bakar solar ke sumber energi yang dapat diperbaharui. Penggunaan cangkang sawit sebagai bahan bakar pada pengeringan crumb rubber memerluakan biaya lebih murah dan secara operasional tidak menghasilkan $\mathrm{CO}_{2}$, sehingga tingkat emisi $\mathrm{CO}_{2}$ maksimum $200 \mathrm{Kg} \mathrm{CO} /$ ton produk untuk industri karet remah dapat terpenuhi.

Pupuk organik adalah pupuk dari bahan organik yang telah mengalami fermentasi atau dekomposisi oleh mikroorganisme yang mengandung unsur hara. Selain itu juga berfungsi membantu memperbaiki struktur tanah dan meningkatkan porositas tanah sehingga tanah gembur dan dapat menyimpan air (Tchobanoglous, 1993)

Waktu dekomposisi pupuk organik sekitar 3 bulan. Proses ini terlalu lama. dengan pembuatan pupuk dari limbah lumpur aktif dan penambahan mikroba EM-4 diharapkan dapat menghasilkan pupuk organik yang memenuhi persyaratan pupuk organik sesuai Permentan No. 79/permentan/SR/140/10/2011 dan SNI 19-7030-2004 dengan waktu selama 40 hari dekomposisi.

\section{BAHAN DAN METODE}

\section{Bahan}

Bahan yang dipergunakan dalam penelitian ini adalah lumpur aktif padat (PT. Hoktong Plaju), abu cangkang sawit (PT. Pinago Utama), sekam padi, air, mikroba EM-4 (PT. Songgolangit Persada dan glukosa $\left(\mathrm{C}_{6} \mathrm{H}_{12} \mathrm{O}_{6}\right)$.

\section{Peralatan}

Peralatan penelitian terdiri seperangkat alat pencacah, penyemprot air, kotak kayu, timbangan, alat gelas, karung rami (goni), cangkul, skop, $\mathrm{pH}$ meter, higrometer, termometer, terpal, pengaduk, jerigen, dan kawat kasa.

\section{Prosedur Penelitian}

Dilakukan penyiapan bahan baku berupa limbah lumpur aktif padat, limbah abu dan limbah sekam padi. Dilakukan pencampuran bahan baku dengan cara pengadukan sesuai dengan perbandingan $(\mathrm{g})$ variasi $A$ terdiri $\left(\mathrm{A}_{1}\right)$ 100:0:0 $\left(A_{2}\right)$ 90:5:5 $\left(A_{3}\right)$ 80:10:10 $\left(A_{4}\right)$ 70:15:15 ( $\left.A_{5}\right)$ 60:20:20 dan faktor $B$ konsentrasi penambahan mikroba $B_{1}$ $(1 \%)$, dan $\mathrm{B}_{2}(2 \%)$. Ditambahkan mikroba EM-4 secara merata sesuai perlakuan, dengan cara melarutkan EM-4 dan glukosa ke dalam air. Siramkan larutan EM-4 secara merata ke dalam campuran, sesuai perlakuan setiap 4 hari sekali. Kompos selanjutnya ditutup dengan karung goni, selama 40 hari pengomposan, pupuk dibalik, dan ditutup kembali. Pengecekan suhu dan kelembaban dilakunan setiap 4 hari sekali. Setelah batas waktu 
pengomposan, pupuk dikeringkan dengan sinar matahari selama 2 hari, sampai penurunan kadar air sebesar 10$20 \%$. Pupuk organik dilakukan pengujian, meliputi visual pupuk, dan unsur makro.

\section{HASIL DAN PEMBAHASAN}

\section{Pengujian Bahan Baku}

Hasil uji nitrogen total pada sekam padi $1,29 \%$, limbah lumpur aktif sekitar $0,22 \%$, dan limbah abu 0,6\%. Kandungan nitrogen dari bahan baku ini akan mempengaruhi kadar nitrogen pupuk organik. Kandungan nitrogen pupuk organik yang dipersyaratkan sesuai SNI adalah minimal $4 \%$.

Hasil pengujian $\mathrm{P}_{2} \mathrm{O}_{5}$ untuk sekam padi $2,11 \%$, limbah lumpur aktif $0,28 \%$, limbah abu 2,44\%. Kandungan $\mathrm{P}_{2} \mathrm{O}_{5}$ ini akan mempengaruhi kadar $\mathrm{P}_{2} \mathrm{O}_{5}$ pupuk organik. Kandungan $\mathrm{P}_{2} \mathrm{O}_{5}$ pupuk organik yang dipersyaratkan sesuai SNI adalah minimal $0.1 \%$.

Hasil uji $\mathrm{K}_{2} \mathrm{O}$ sekam padi 2,11\%, limbah lumpur aktif $0,63 \%$, dan limbah abu $1,41 \%$. Kandungan $\mathrm{K}_{2} \mathrm{O}$ bahan baku akan mempengaruhi kadar $\mathrm{K}_{2} \mathrm{O}$ pupuk organik. Kandungan $\mathrm{K}_{2} \mathrm{O}$ pupuk organik yang dipersyaratkan sesuai SNI adalah minimal $0.2 \%$.

\section{Pengujian Pupuk Secara Visual Bau}

Bau pupuk organik matang seperti tanah dan tidak berbau busuk meskipun pupuk organik berasal dari limbah. Pupuk organik yang berbau tidak sedap, pupuk tersebut terjadi fermentasi anaerobik dan menghasilkan senyawasenyawa berbau yang mungkin berbahaya bagi tanaman (Wang et al., 2007), dan apabila pupuk organik masih berbau seperti bahan mentahnya berarti pupuk organik masih belum matang. Hasil pengujian bau pupuk organik dari semua perlakuan berbau tanah, sesuai SNI 19-7030-2004.

\section{Warna}

Pupuk organik matang berwarna coklat kehitaman (Sahwan et al., 2011). Perubahan warna pupuk dari warna bahan baku menjadi coklat kehitaman dikarenakan proses pengomposan telah optimal. Suhu selama proses pengomposan sesuai, didukung hasil pengujian suhu setiap 4 (empat) hari selama kompos berkisar antara $40-59{ }^{\circ} \mathrm{C}$. Hasil pengujian warna pupuk pada semua perlakuan berwarna coklat, sesuai SNI 19-7030-2004

\section{Kadar Air}

Kadar air pupuk setelah pengeringan berkisar antara 5,65\% sampai dengan $6.04 \%$. Kadar air tertinggi terdapat pada perlakuan $\mathrm{A}_{2} \mathrm{~B}_{2}$ dan kadar air terendah terdapat pada perlakuan $A_{1} B_{1}$ Kadar air terendah pada perlakuan lumpur aktif padat : limbah abu dan limbah sekam padi $\left(A_{1}\right)$ 100:0:0 dengan penambahan mikroba $1 \%$. Limbah lumpur aktif padat tanpa penambahan bahan lain dan penambahan mikroba sedikit (1\%), kemungkinan tidak terjadi dekomposisi yang optimal sehingga tidak menghasilkan pupuk yang baik.

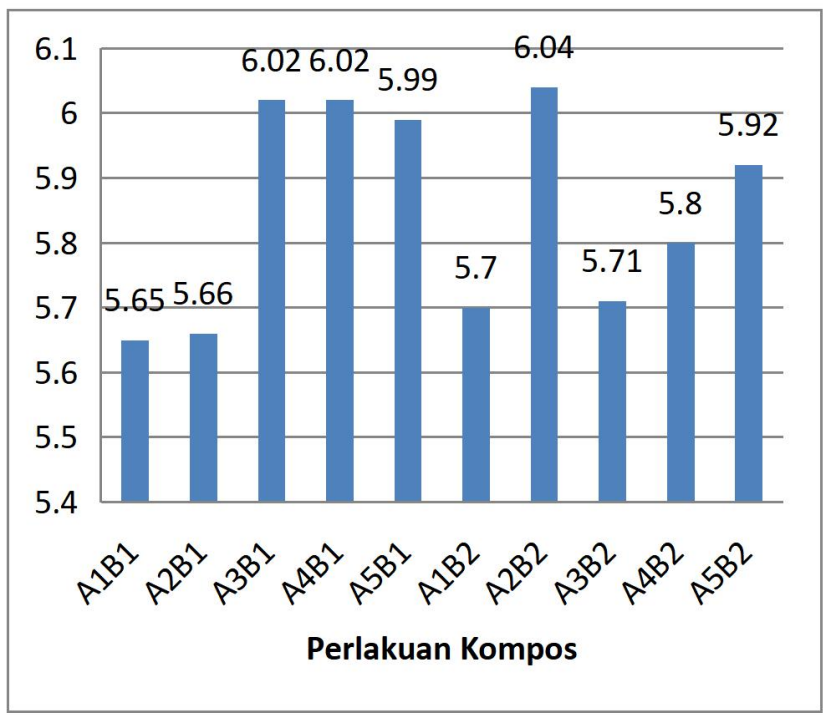

Gambar 1. Nilai kadar air

Data ini didukung dengan hasil uji kalium yang rendah dan tidak memenuhi persyaratan (minimal 0,20\%) pada perlakuan $A_{1} B_{1}$ dengan hasil $0,18 \%$. Kadar air pupuk yang dipersyaratkan adalah maks. $50 \%$, sehingga semua perlakuan memenuhi persyaratan. Pengujian kadar air pada Gambar 1. 


\section{Kadar C- Organik}

Karbon membentuk karbohidrat, lemak, dan protein untuk pertumbuhan tanaman. Selain itu juga, memperkuat selulosa dinding sel tanaman. (Mulyono, 2014). Hasil pengujian kadar C-organik dapat dilihat pada Gambar 2.

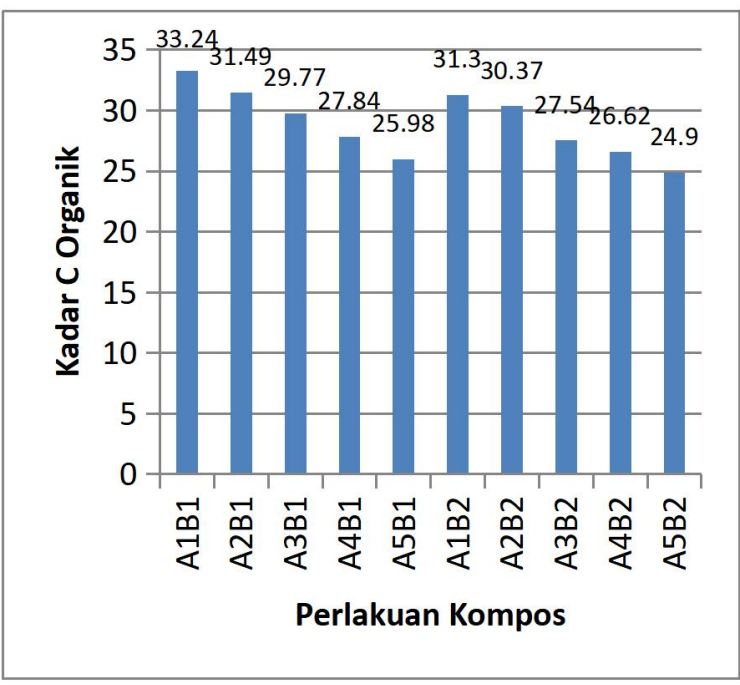

Gambar 2. Nilai kadar C-organik

Hasil pengujian C-organik setelah pengomposan dari semua perlakuan akan menurun apabila dibandingkan dengan kadar C-Organik dari bahan baku. Menurunnya kadar $\mathrm{C}$-organik ini disebabkan karena mikro organisme dalam pengomposan menggunakan karbon dari proses pengomposan sebagai sumber energinya atau aktivitas metabolismenya (Graves, 2007). Nilai kandungan C-organik paling rendah terjadi pada perlakuan $\mathrm{A}_{5} \mathrm{~B}_{2}(24,90 \%)$ dan kandungan $\mathrm{C}$-organik yang tertinggi terdapat pada perlakuan $A_{1} B_{1}(33,24 \%)$. Syarat mutu C-organik yang ditetapkan pada SNI adalah berkisar antara $27 \mathrm{~s} / \mathrm{d}$ $58 \%$. Dari semua perlakuan, perlakuan yang memenuhi persyaratan $\mathrm{SNI}$ adalah $A_{1} B_{1}, A_{2} B_{1}, A_{3} B_{1}, A_{1} B_{2}, A_{2} B_{2}$ dan $A_{3} B_{2}$ sedang kandungan $C$-organik yang tidak memenuhi SNI terdapat pada perlakuan $A_{4} B_{1}, A_{5} B_{1}, A_{4} B_{1}$, dan $A_{5} B_{2}$. Kadar Corganik pada perlakuan yang rendah ini disebabkan karena mikroorganisme yang bekerja lebih banyak sehingga jumlah karbon dari bahan baku digunakan oleh mikroorganisme untuk pertumbuhannya juga rendah. Penguraian bahan organik dapat melalui proses fermentasi. Tahap awal, bahan diubah menjadi senyawa yang lebih sederhana seperti gula, gliserol, asam lemak dan asam amino, dilanjutkan aerobik maupun anaerob (Fitria, Y, 2008). Proses aerobik dan anaerobik selanjutnya :

Aerobik: C org. $+02-\mathrm{C}_{5} \mathrm{H}_{7} \mathrm{O}_{2} \mathrm{~N}+\mathrm{CO}_{2}$

Anaerob : $\mathrm{C}$ org.teroksidasi + asam organik-sel mikroba + metana + $\mathrm{CO} 2+$ alkohol

Menurut Chairunisa et al. (2017), sekam padi mengandung C-organik sebesar $8,7 \%$, abu boiler mengandung $5,79 \%$ (Hidayati dan Indrayanti, 2016) dan hasil pengujian limbah lumpur aktif mengandung C-organik 32,16\%. Apabila dilihat dari perbandingan ke tiga bahan baku tersebut maka perlakuan $A_{1} B_{1}$, $A_{2} B_{1}, \quad A_{3} B_{1}, \quad A_{1} B_{2}, \quad A_{2} B_{2}$ merupakan perbandingan dengan bahan baku dominan berupa lumpur aktif dan sekam padi. Perbandingan ini dengan penambahan bakteri yang sesuai akan menghasilkan nilai C-organik yang memenuhi persyaratan SNI. Untuk perlakuan yang tidak memenuhi $\mathrm{SNI}$ seperti $A_{4} B_{1}, A_{5} B_{1}, A_{4} B_{1}$, dan $A_{5} B_{2}$, merupakan pupuk dengan perbadingan yang didominasi dengan abu dan sekam padi.

Kandungan C-organik akan menurun selama pengomposan. Waktu penurunan kandungan C-organik mulai pada hari ke 5 pengomposan (Suherman, 2014). Hasil penelitian ini didukung oleh Yeoh, et al. (2012), bahwa penurunan kandungan C-organik mulai pada hari ke 7 pengomposan, hal ini disebabkan karena adanya aktifitas organisme seperti fungi lignolitik atau fungi selulotik yang membutuhkan karbon organik sebagai sumber makanan. Hasil pengujian lumpur aktif kering sebagai bahan baku mengandung bakteri lignolitik sebesar 4,6 $\times 10^{3} \mathrm{CFU} / \mathrm{ml}$, bakteri selulitik sebesar $1,45 \times 10^{5}$ $\mathrm{CFU} / \mathrm{ml}$, fungi lignolitik sebesar $1,55 \mathrm{X}$ $10^{2} \mathrm{CFU} / \mathrm{ml}$ dan fungi selulotik sebesar $4,05 \times 10^{3} \mathrm{CFU} / \mathrm{ml}$. Bakteri yang terkandung dalam lumpur aktif ini akan menguraikan bahan baku pupuk organik. (Nurhayati, 2016). 


\section{Kadar Nitrogen}

Nitrogen merupakan sumber energi untuk mikroorganisme dalam tanah untuk proses pelapukan atau dekomposisi bahan organik. Nitrogen juga diperlukan oleh tanaman untuk proses fotosintesis untuk menghasilkan energi. Hasil pengujian kadar nitrogen pada pupuk organik dapat dilihat pada Gambar 3.

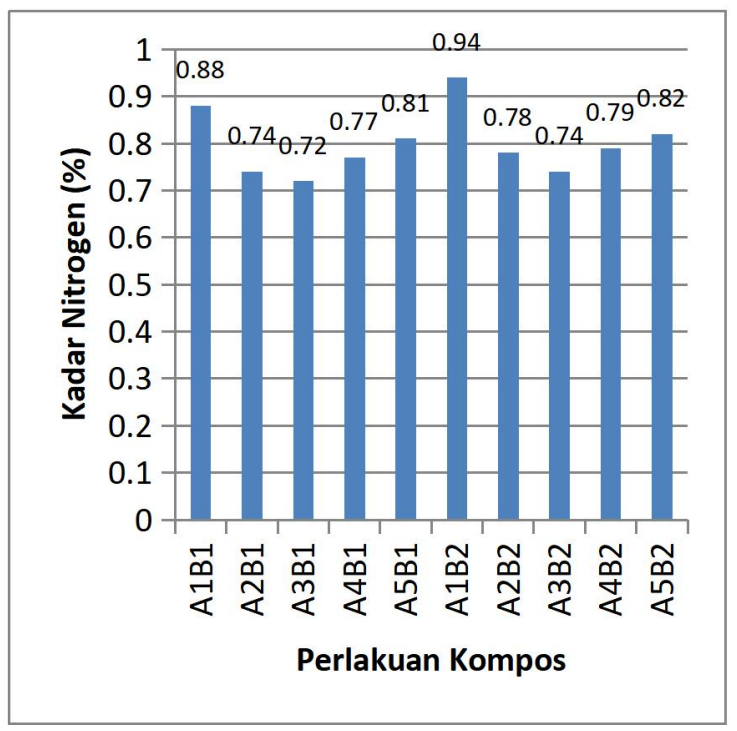

Gambar 3. Nilai kadar nitrogen

Hasil uji kandungan nitrogen pada
pupuk organik setelah masa pengomposan bervariasi. Kadar nitrogen pupuk organik semua perlakuan berkisar antara $0,72 \%$ s/d 0,79\%. Kadar nitrogen pupuk organik menurun apabila dibandingkan dengan kadar nitrogen pada bahan baku untuk sekam padi $(1,29 \%)$ maupun kadar nitrogen pada abu $(0,6 \%)$ dan nitrogen pada lumpur aktif $(1,1 \%)$. Penurunan kadar nitrogen pupuk organik disebabkan terjadinya proses denitrifikasi oleh bakteri thiobacillusdenitrificans yang menyebabkan unsur nitrogen akan mengalami penurunan akibat pelepasan nitrogen ke udara. Selama proses pengomposan, limbah dan lumpur aktif mengalami penurunan kadar nitrogen (Suherman, 2014). Hasil pengujian kadar nitrogen tertinggi pada $A_{2} B_{2}(0,94 \%)$ dan terendah pada perlakuan $A_{1} B_{3}(0,72 \%)$. Kadar nitrogen pupuk organik setelah pengomposan dari semua perlakuan memenuhi SNI (standar minimum 0,40\%).
Menurut Suherman et al., (2014) dan Yoeh et al., (2012), kenaikan kadar nitrogen pada proses pengomposan terjadi pada hari ke $0-14$, dan menurun kembali. Peningkatan ini dikarenakan adanya mikroorganisme yang optimum pada proses dekomposisi sehingga senyawa organik berjalan dengan optimal. Menurut Hiraishi et al., (1989) dalam Herlambang, (2013), adanya aktifitas mikroorganisme pada lumpur aktif seperti Comamonas-Pseudomonas, Alkaligenes, Pseudomonas (Kelompok Florescent, Flavobacterium-Cytophaga, Coryneform, Paracoccu, Unidentified (gram negative rods, Aeromomas, Bacillus, Micrococcus, Arthrobacter, dan Aureobacterium-Microbacterium dan dengan penambahan oksigen yang cukup akan menyebabkan terjadinya penambahan kandungan nitrogen baik dalam bentuk nitrat maupun nitrogen total. Peningkatan kadar nitrogen ini ditunjang hasil pengujian limbah lumpur aktif cumb rubber, mengandung bakteri lignolitik berkisar 4,6 X $10^{3} \mathrm{CFU} / \mathrm{ml}$, bakteri selulitik berkisar $1,45 \times 10^{5}$ $\mathrm{CFU} / \mathrm{ml}$, fungi lignolitik berkisar $1,55 \mathrm{X}$ $10^{2} \mathrm{CFU} / \mathrm{ml}$ dan fungi selulotik berkisar $4,05 \times 10^{3} \mathrm{CFU} / \mathrm{ml}$. Menurut Suherman et al., (2014), peningkatan kandungan nitrogen total ini dikarenakan proses dekomposisi organik oleh mikroorganisme yang akan mengubah amonia menjadi nitrat. Menurut Jalaluddin et al., (2016), suhu yang optimum untuk proses dekomposisi berkisar antara $40-60{ }^{\circ} \mathrm{C}$, suhu yang terlalu tinggi menjadikan mikroorganisme mati, sedang terlalu rendah mikroorganisme tidak bekerja optimal atau dorman. Pengukuran suhu dalam penelitian dilakukan setiap 4 hari, untuk menunjang proses dekomposisi.

\section{Kadar $\mathrm{P}_{2} \mathrm{O}_{5}$ \\ Unsur fosfor berguna untuk pertumbuhan tanaman seperti} pertumbuhan akar, pembentukan buah dan pembentukan biji (Santi, 2008). Kekurangan fosfor pada tanaman akan menyebabkan pembelahan sel tertunda, 
sehingga pertumbuhan sel tidak optimal, daun berwarna kuningan dan akhirnya tanaman menjadi kerdil, sedangkan kelebihan unsur fosfor pada tanaman akan merangsang kematangan sehingga buah matang terlalu dini. Pengujian $\mathrm{P}_{2} \mathrm{O}_{5}$ dilakukan setelah pengomposan berakhir, untuk mengetahui kandungan P-total yang terbaik setelah proses pengomposan (Gambar 4).

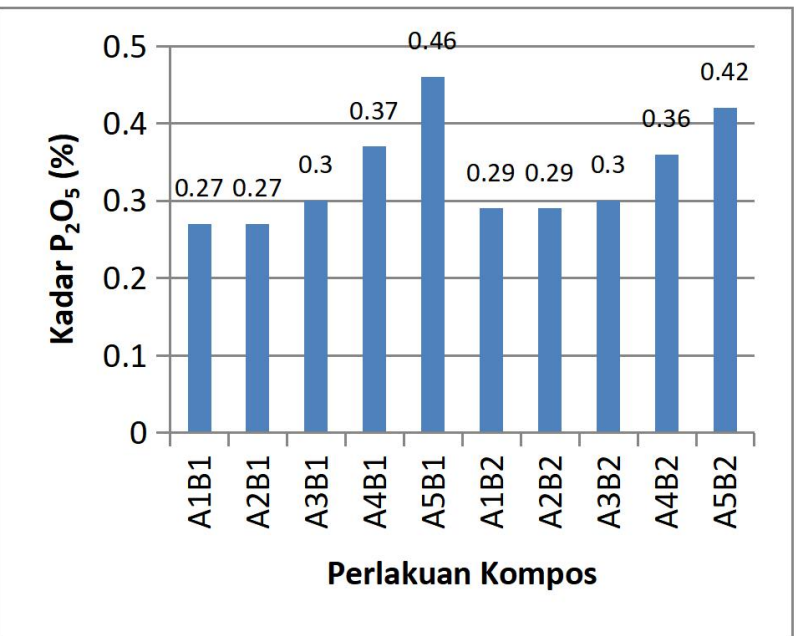

Gambar 4. Hasil pengujian $\mathrm{P}_{2} \mathrm{O}_{5}$

Hasil analisa kadar fosfor setelah masa pengomposan menurun apabila dibandingkan dengan kadar fosfor pada bahan baku. Bervariasinya kadar fosfor pupuk organik tersebut dikarenakan kadar fosfor pada bahan baku sekam padi berkisar 2,11(\%) maupun kadar fosfor pada lumpur $(0,22 \%)$ dan kadar fosfor pada limbah abu sebesar (2,44\%) sehingga perbedaan perbandingan ini menyebabkan kadar fosfor bervariasi.

Hasil pengujian kadar fosfor tertinggi pada $A_{5} B_{1}(0,46 \%)$, dan terendah pada $A_{1} B_{1}$ dan $A_{2} B_{1}(0,27 \%)$. Hasil pengujian kadar fosfor dari ke semua perlakuan memenuhi persyaratan SNI 19-7030-2004 dimana kadar fosfor yang dipersyaratkan adalah minimum $0,10 \%$. Kandungan fosfor yang tinggi terdapat perlakuan dengan perbandinggan bahan baku limbah abu dan sekam yang tinggi, sehingga menghasilkan forfor yang tinggi pada pupuk organiknya.
Kalium berfungsi untuk meningkatkan ketahanan tanaman terhadap hama dan penyakit (Santi, 2008). Pengujian $\mathrm{K}_{2} \mathrm{O}$ bertujuan untuk mengetahui kandungan $\mathrm{K}_{2} \mathrm{O}$ total perlakuan terbaik. Kadar $\mathrm{K}_{2} \mathrm{O}$ pada Gambar 5

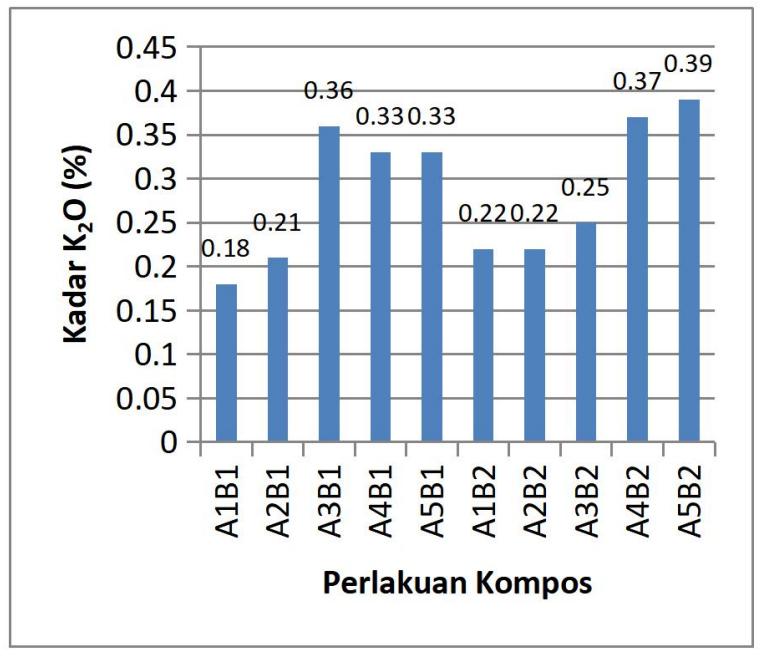

Gambar 5. Hasil pengujian $\mathrm{K}_{2} \mathrm{O}$

Hasil uji kadar kalium setelah pupuk organik telah matang terjadi penurunan. Kadar kalium semua perlakuan sebesar $0,18 \%$ s/d $0,39 \%$. Kandungan kalium pupuk organik menurun apabila dibandingkan dengan kadar kalium sekam padi $(1,21 \%)$ maupun pada limbah lumpur aktif $(0,3 \%)$.dan limbah abu $(1,41 \%)$. Kadar Kalium pupuk tertinggi terdapat pada perbandingan bahan sekam dan limbah abu yang tinggi, dan jumlah bakteri yang tinggi akan meningkatkan jumlah kalium.

Hasil pengujian kadar kalium terendah pada $A_{1} B_{1} \quad(0,18 \%)$, dan tertinggi pada $\mathrm{A}_{5} \mathrm{~B}_{2} \quad(0,39 \%)$. Kadar kalium yang meningkat ini linier dengan peningkatan jumlah abu sawit dan sekam padi pada bahan baku, dengan kata lain penambahan jumlah abu dan sekam padi akan meningkatkan kadar $\mathrm{K}_{2} \mathrm{O}$ pada pupuk organik. Hasil uji kadar kalium semua perlakuan memenuhi persyaratan mutu pupuk organik dari sampah organik domestik (persyaratan $\mathrm{K}_{2} \mathrm{O}$ minimal $0,20 \%$ ), kecuali perlakuan $A_{1} B_{1}$ dengan nilai sebesar $0,18 \%$. 


\section{KESIMPULAN}

Hasil penelitian pembuatan pupuk organik dengan EM-4 dengan bahan baku limbah lumpur aktif padat, limbah abu dan limbah sekam padi diperoleh hasil terbaik pada perlakuan $A_{5} B_{2}$ dengan nilai unsur hara makro : Corganik $(24,90 \%)$, nitrogen total $(0,82 \%)$, $\mathrm{P}_{2} \mathrm{O}_{5}(0,42 \%), \mathrm{K}_{2} \mathrm{O}(0,39 \%)$ memenuhi persyaratan mutu pupuk organik dari sampah organik domestik nomor SNI 197030-2004 dan Permentan nomor nomor 79/permentan/SR/140/10/2011.

\section{UCAPAN TERIMA KASIH}

Penulis mengucapkan terima kasih kepada Kepala Baristand Industri Palembang, anggota tim penelitian, pihak yang memberikan dukungan pendanaan, fasilitas sehingga penelitian ini dapat diselesaikan.

\section{DAFTAR PUSTAKA}

Anonim. (2011). Pupuk Organik dan Pembenah Tanah. Permentan nomor nomor 79/permentan/SR/140/10/2011.

BSN (Badan Standardisasi Nasional). (2004). SNI 19-7030-2004. Spesifikasi Pupuk Organik dari Sampah Organik Domestik.

Chairunisa, RA, H. Hanum, dan B. Hidayat (2017). Aplikasi Bahan Organik dan Sekam Padi untuk Meningkatkan COrganik Pada Tanah Sawah. Jurnal Agroekotehnologi. Vol 5 No. 3 (64) 494-499.

Ferguson, K. (1991). Enviromental Solution for the Pulp and Paper Industry.Miller Freeman, San Fransisco.171-176.

Fitria, Y. (2008). Pembuatan Pupuk Organik Cair dari Limbah Cair Industri Perikanan Menggunakan Asam Asetat dan EM-4. Skripsi. Fak. Perikanan dan dan IImu Kelautan. IPB.Bogor.

Graves, R.E. (2000). National Engineering Handbook. United States Department of Agriculture.

Herlambang, A. (2003). Pengolahan Limbah Tekstil dengan Sistim Lumpur Aktif. Makalah. Jakarta. Direktorat Jenderal Lingkungan. BPPT.

Hidayati. (2011). Analisis Kualitas Pupuk Organik dari Limbah Organik Pasar
Tradisional Tanjungsari Sumedang

(Skipsi). Bandung. Fakultas

Peternakan. Universitas Padjajaran.

Nurhayati, C. dan Andayani, O. (2016). Pengaruh Lumpur Aktif Cair dari Pabrik Crumb Rubber Sebagai Dekomposer Pupuk Organik dari Kotoran Ayam dan Tandan Kosong Kelapa Sawit. Jurnal Dinamika. 7(1) :19-29.

Jalaluddin, Nasrul Z.A, Safrina, R.(2016). Pengolahan Sampah Organik Buahbuahan menjadi Pupuk dengan Menggunakan Efektif Mikroorganisme. Jurnal Teknologi Kimia Unimal. 5:1. 1729.

Sahwan, F.L, Wahyono, S dan F. Suryanto, (2011). Evaluasi Mikroba Fungsional pada Pupuk Organik Kompos (POK) Murni dan Pupuk Organik Granul (POG) yang Diperkaya dengan Pupuk Hayati. Journal Teknologi Lingkungan. 12(2): 187-196.

Santi, S.S. (2008). Kajian Pemanfaatan Limbah Nilam untuk Pupuk Cair Organik dengan Proses Fermentasi. Jurnal Teknik Kimia 2(2): 170-175

Suherman, I, A. Awaludin dan Itnawita. (2014). Analisis Kualitas Pupuk Organik dari Campuran Tandan Kosong Kelapa Sawit dengan Kotoran Ayam Menggunakan Limbah Cair Pabrik Kelapa Sawit dan EM-4. Majalah JOM FMIPA 1 (2): 195-202.

Suwardin (2015). Penggunaan Garam Ammonium dalam Produksi Karet Viscositas Rendah dari Lateks. Journal Penelitian Karet, 33(2):193-202.

Wang, Wenjian, and Chen, G. (2007). System Identification of Highway Bridge from Earthquake-Induced Responses Using Neural Network. Structural Engineering research Frontiers.

Tchobanoglous, Theisien and Vigil. (1993). Integrated Solid Waste Management Mc Graw Hill. Internal Editions.

Yeoh, C.Y., Chin, N.L., Tan, C.S.,Ooi, H.S. (2012). Industrial Scale CoComposting of Palm Oil Mill Waste with Starter Cultures. Journal of Food Agriculture and Enviroment. 10 : 771:775. 